\title{
The Analysis of Fine Motor Skills and Early Childhood Creativity through Weaving Activities
}

\section{| Rahimah |}

Faculty of Islamic Religion, Universitas Muhammadiyah Sumatera Utara, Indonesia

Rahimah@umsu.ac.id

DOI: https://doi.org/10.47175/rissj.v2i4.340

\begin{abstract}
Fine motor improvement is exceptionally critical for a child's in general advancement. Early childhood still frequently have trouble moving their fingers for exercises such as cutting, drawing, coloring, tearing, collapsing, orchestrating and weaving. This consider points to portray the capacity of fine motor abilities and inventiveness of early childhood through weaving exercises. The investigate strategy utilized may be a writing survey conducted by collecting information or based on logical papers that interface investigate with existing writing to unravel a issue. The strategy of collecting library information is by perusing and taking notes and overseeing inquire about materials and after that concluding the investigate materials. The comes about appeared that the improvement of fine motor abilities and imagination in early childhood requires eye and hand coordination, such as performing manipulative developments, and communicating themselves through craftsmanship with weaving exercises.

KEYWORDS

fine motor skills; creativity; weaving activities
\end{abstract}

\section{INTRODUCTION}

Education is one of the necessities of life that is needed to develop human competence through learning. Education includes the process of human life and its interaction with the environment in order to develop all the potential possessed in accordance with the stages of development in order to function optimally. Prayitno (2009:203) explains that education is a vehicle for human development, in which education becomes a medium for the glorification of humanity.

Education for early childhood is in the form of efforts to foster, nurture, and stimulate to guide, so that it will produce children's abilities and skills. According to Siswanto (2008:2), "Children's education must start early so that children can develop their potential optimally with the aim that children who attend early childhood become more independent, disciplined, and easily directed to absorb knowledge optimally".

Early childhood is in the age range 0 to 6 years, kindergarten age children are in the age range 4-6 years. This limitation is in accordance with the limitations according to Law Number 20 of 2003 concerning the National Education System which states that "kindergarten is a formal education in the early childhood education path that educates children aged 4-6 years" (Suryana, 2011:31-32).

The purpose of early childhood education is to help lay the foundation for developing attitudes, behaviors, cognitions, skills and what children need in later life for growth and development. Early childhood education is held with the aim of facilitating all children's abilities, so that early childhood education institutions need to provide various activities that support children's growth and development from various aspects of child development, namely cognitive, language, physical motoric, social emotional, religious, moral and art. 
Various studies in the field of neuroscience show that $50 \%$ of children's intelligence is formed within the first 4 years. Then brain development reaches $80 \%$ in children aged 8 years and $100 \%$ at the age of 18 years (Suyanto, 2005: 6). In addition, Suryana (2018:159) describes the motor development of children, especially fine motor skills aged 4-5, as follows: 1) Draw something meaningful for children; 2) Using finger gestures during finger play; 3) Tracing the box image; 4) Coloring with stripes; 5) Cut out simple shapes like geometry. Fine motor development in children this age will be able to affect the creativity of the child.

According to Susanto (2011: 164) fine motor skills are fine developments that include as it were certain parts that are carried out by little muscles as it were, since they don't require vitality but fine motor skills require careful and precise coordination with patience and concentration. By increasing fine motor skills, children can be more creative, such as cutting paper in straight lines or zigzags, utilizing clips to connect two sheets of paper, sewing designs, weaving papers. In any case, not all children have the development to ace this capacity at the same arrange.

With regard to the advancement of fine engine aptitudes that frequently happens in early childhood, particularly kindergartens, children still have trouble moving their fingers for exercises such as cutting, drawing, collapsing, and filling in designs by sticking little objects, etc. This is due to several things that cause these problems such as limited media, children cannot hold scissors properly, cannot stick according to patterns, have not been able to weave following patterns, as well as methods and strategies that are not appropriate in learning.

Based on observations made by researchers at RA Nurhidayah Sei Rattan, fine motor skills and creativity are developed through matching, coloring, writing, folding, crocheting, collage, sticking, weaving, etc. activities. but there is still a need for more innovative media and activities and more interesting materials. Actions that are appropriate to problems that arise from the development of fine motor skills and creativity are through weaving activities whose activities are very interesting and innovative that require good eye and hand coordination, and are able to train children's concentration. The activity of weaving is closely related to the development of fine motor skills of children, because fine motor skills are skills that require the control of small and fine muscles to achieve successful execution of skills.

(Ahmad Husaeri, 2018), Based on research with the classroom action research method with the title "Improving Fine Motor Ability Through Weaving Activities in Group A Children" found that the results of classical research showed that the percentage of children's fine motor skills observed was eye and hand coordination and could control hand movements using finger muscles. The results of the pre-cycle $29 \%$ increased in the first cycle to $70 \%$, after improving the planning in the second cycle increased $94 \%$. Based on the results of the study, it can be concluded that weaving activities can improve children's fine motor skills. (Lathipah Hasanah, 2017), Based on the results of research with a preexperimental method with a one-Group-pretest-posttest design with the title "Weaving Activities to Improve Fine Motor Skills for Children Age 4-5 Years" through weaving activities can be an alternative to improve motor skills of children aged 4-5 years. The achievement of children's fine motor skills is characterized by the ability to coordinate eyes with hands, perform manipulative movements, and express themselves through works of art with weaving activities.

In addition, this weaving activity will be able to develop children's creativity as well. Creativity in education is very necessary. Regarding creativity, there are several problems 
that occur in early childhood, including children who have not been able to make something unique according to their imagination, always as exemplified by the teacher.

(Eva Susanti, 2020) Based on research using the classroom action method with the title "Efforts to Improve Children's Fine Motor Skills Through Weaving Coconut Leaves Activities in Group B." The results showed that Cycle I teacher activities obtained a percentage score of 3.21 in the good category. The improvement of children's fine motor skills in Cycle I obtained a percentage score of $61 \%$ with the category developing as expected. Meanwhile, in Cycle II, the teacher's activities obtained a percentage of 3.89, with a very good category. Cycle II of coconut leaf weaving activities has increased to a percentage of $80 \%$ with a very well developed category. The results showed that the activity of weaving coconut leaves can improve children's fine motor skills.

(Ucu Khoirunnisa, 2019) This study uses a correlational quantitative method, with the title " The relationship between weaving exercises and fine engine aptitudes of early childhood: Inquire about in Gather B RA Al-Gozali Cileunyi Bandung" The comes about of calculations on variable $X$ (Weaving Exercises) gotten a esteem an normal of 85. This esteem is on a scale of 80-100 with an awfully great translation. Whereas the comes about of calculations on the variable Y (Fine Engine Aptitudes for Early Childhood) gotten an normal esteem of 78 . This esteem is on a scale of $70-79$ with great elucidation. The relationship between weaving exercises on fine engine aptitudes of early childhood gotten a relationship coefficient of 0.85 . This correlation coefficient is included within the exceptionally solid category since it is on a scale of $0.80-0.100$. The comes about of the noteworthiness test gotten the calculated cost $=6.208$, which is more prominent than the table cost $=2.131$. That's , $\mathrm{H} 0$ is rejected and $\mathrm{Ha}$ is acknowledged, in other words there's a noteworthy positive relationship between weaving exercises on fine engine ski

Therefore, a suitable solution or alternative is needed regarding learning in early childhood so that fine motor skills in early childhood can be developed and creativity can be carried out through weaving activities. Therefore, researchers are interested in conducting research on the Analysis of Fine Motor Skills and Early Childhood Creativity through Weaving Activities.

\section{LITERATURE REVIEW}

Mayesky (2009:4) argues that imagination may be a way of considering and acting or making something unique for people and acknowledged by individuals or others. Carl Roger and Abraham Maslow in Jamaris (2006:56-58) recommend imagination as one viewpoint of identity related to self-actualization. Mulyadi (2000:30) proposes that creativity can be characterized as the capacity to form modern combinations based on existing information, data or components. Inventiveness can moreover be translated as an capacity that reflects familiarity, adaptability, and inventiveness in considering. So from the above ideas it can be concluded that creativity is the ability to develop, make something, enrich and detail an idea.

\section{Weaving Activities}

Pamadhi defines that weaving is a technique of weaving warp and weft. The warp is the part of the woven that sticks up (vertical) which is perpendicular to the weaver, while the weft is the part of the woven that sticks out to the side (horizontally) which will be inserted into the warp and the direction is opposite or transverse to the warp. Without the warp and weft, the woven will not be processed and will not produce woven works (Pamadhi Hajar and Evan Sukardi, 2015). Creative art for kindergarten children in addition to drawing, 
painting, printing, mosaic, montage, collage, folding, cutting activities are also given an introduction to weaving skills (Sumanto 2005: 119).

Weaving is the activity of weaving ribbons or knots arranged according to certain directions and notes. Weaving is also defined as a technique of weaving the warp with the weft. Lungsi is a ribbon or weave that is perpendicular to the weaver. Weft is a ribbon or weft that is inserted into the warp and the direction is opposite or transverse to the warp. Based on the description above, we can conclude that weaving in this study is an activity carried out by inserting or overlapping parts of the woven ribbon alternately with simple motifs.

The weaving activity is carried out by arranging the parts of the woven material (ribbon) to form a woven motif or form a woven model. Through weaving skills, it is hoped that kindergarten children will develop artistic competence, perseverance, patience, and dexterity in line with the development of their artistic taste. Weaving is a skill activity that aims to produce various objects or articles of use and art objects, which are carried out by interlocking or overlapping parts of the woven tape alternately.

\section{RESEARCH METHODS}

This research uses literature review, and in research studies, literature review is an important part of the general stages of research methods. Sanusi (2016: 32) Library research or library research, namely research activities carried out by collecting data or based on scientific writings aimed at the object of research or data collection being literature, or a study is then carried out to solve a problem and in depth to the material Relevant library materials.

Researchers need to know exactly where to get scientific information before looking at library materials. The sources used include; textbooks, scientific journals, research results in the form of theses, theses, dissertations, and the internet, as well as other relevant sources.

The reasons for using library research studies are: 1) research problems can only be solved through library research, 2) literature studies require separate steps, namely preliminary studies to understand more deeply the new symptoms that are developing in the field or in the community, 3) library data remains reliable to answer their research questions. Thus, library research by utilizing library resources to obtain research data so that library research can limit activities only to library collection materials without requiring field research.

\section{RESULTS AND DISCUSSION}

\section{The Relationship of Weaving Activities with Fine Motor Skills for Early Childhood}

Research that supports that an increase in fine motor skills can be achieved from weaving activities is research conducted by (Ucu Khoerunisa, 2019) which proves that there is a very significant increase in fine motor skills. in other words, there's a critical positive relationship between weaving exercises on fine engine aptitudes in early childhood. The comes about of his inquire about expressed that by applying the strategy of allotting errands through weaving exercises can move forward children's fine engine aptitudes. Aspects of fine motor skills studied are related to these muscle and nerve groups which will later be able to develop fine motor movements.

Weaving is a learning activity in kindergarten that can improve children's fine motor development, so that with this weaving activity children can practice patience, accuracy, foresight, togetherness, and especially train hand movement coordination. The 
coordination of the child's hand movements needs to be trained so that the child's hand movements are accustomed to good things.

In general, early childhood children prefer something unique and interesting and beautiful. Therefore, so that children like weaving activities and have no difficulty in making plaits, educators or teachers must be able to provide materials that will be used to make plaits, namely materials that are interesting, liked by children and easy to obtain. The materials used to make crafts at school must be adapted to the child's developmental level (Widiastini et al., 2014).

Similar research was also conducted by (Oktavia Nuraeni, 2014) that there was an increase in fine motor development through weaving activities with paper. The results showed that there was a percentage increase in fine motor skills through children's weaving activities that exceeded the success indicator, which was $76 \%$. The success was carried out with the following steps: (1) the explanation of the steps in weaving was further clarified by the way the children followed "top-down" and "bottom-up" when the teacher gave an example of weaving, (2) the paper that The colors used are buffalo paper so that it can attract children's interest in weaving because buffalo paper is thicker than origami and manila paper, (3) the paper for weaving is shaped according to the theme, and (4) a reward is given in the form of animated lollipops.

It is said that this weaving activity was chosen to improve fine motor skills because this collage activity in learning is varied and not monotonous and can use concrete media such as natural materials and certain materials (Misiyanti et al., 2014) so that this will make children more comfortable. interest and improve their fine motor skills. From the results of several studies that have been carried out, it can be concluded that weaving activities can improve children's fine motor skills. Because through these activities, children can practice fine motor movements and eye coordination with interesting and unique activities. Therefore, the weaving activity is one of the learning activities that can be carried out to help children's fine motor development.

The materials used to create plaits are not only limited but can use various types of natural and artificial materials freely both in terms of shape, size, and type. Weaving materials can be in the form of natural materials, artificial materials, semi-finished materials, finished materials, waste/used materials and so on. There are several kinds of woven materials that can be used in practical activities, namely: banana leaves, coconut leaves, paper, ropes, and ribbons. So the results of this study can be concluded that weaving activities can develop children's fine motor skills, because with weaving activities, children will be able to train children's accuracy, patience, foresight, and neatness, in making the results with eye and hand coordination so that children will develop fine motor skills.

\section{The Relationship between Weaving Activities and Early Childhood Creativity}

In early childhood education, one aspect that needs to be developed is creativity, because with the development of creativity a child will gain experiences in creating something, imagining and obtaining new, meaningful and useful things. A child can be said to be creative if he has fulfilled the requirements of fluency and flexibility in finding solutions to a problem. Children will come up with various alternative ideas called doing fluency. Furthermore, the child will consider the best solution. When children want something, they need fluency as preparation or brainstorming. Then the child will do various thoughts and considerations, how to make what he does succeed. He will choose one alternative solution that is in his mind. Children do flexibility because the context begins to speak. Apparently, 
there will be obstacles in its implementation. If then the child succeeds in solving the problem, then he is called creative (Miranda, 2016).

As for the characteristics of early childhood creativity, Munandar (2009:10) explains the characteristics of creativity which he divides into two, namely characteristics related to the ability to think creatively (cognitive) and characteristics related to attitudes or feelings (non-cognitive). The characteristics related to the ability to think creatively or cognitively (aptitude) include: 1) Fluent thinking skills, namely solving problems, questions, giving many ways or suggestions for doing various things and always thinking about more than one answer; 2) Flexible or flexible thinking skills, namely generating varied ideas, answers or questions, being able to see a problem from different perspectives; 3) Original thinking skills, namely being able to give birth to new and unique expressions, and being able to make common combinations of parts or elements. 4) Detailing or elaborating skills, namely being able to develop an idea or product, and adding or detailing in detail an object, idea, or situation so that it becomes more interesting. 5) Assessing skills, namely determining the benchmark for self-assessment and determining whether a question is correct, a healthy plan, or a wise action, is able to make decisions in open situations, and not only generate ideas but also implement them.

The materials used to create plaits are not only limited but can use various types of natural and artificial materials freely both in terms of shape, size, and type. Weaving materials can be in the form of natural materials, artificial materials, semi-finished materials, finished materials, waste/used materials and so on. There are several kinds of woven materials that can be used in practical activities, namely: banana leaves, coconut leaves, paper, ropes, and ribbons. So the results of this study can be concluded that weaving activities can develop children's fine motor skills, because with weaving activities, children will be able to train children's accuracy, patience, foresight, and neatness, in making the results with eye and hand coordination so that children will develop fine motor skills.

\section{CONCLUSION}

One of the achievements that teachers must contribute is the development of fine motor skills and creativity. Fine motor development is related to hand and finger movements that coordinate with the eyes. Because weaving activities require concentration and creativity in placing and following patterns, it can make children more creative and solve problems, and creativity must also be developed because it provides solutions and benefits that can be achieved through weaving practice. Therefore, it can be concluded that the development of fine motor skills and creativity in early childhood requires eye-hand coordination, perform manipulative movements to produce shapes using various media, and express themselves through artistic activities.

\section{REFERENCES}

Anwar, Sanusi. (2016). Metodologi Penelitian Bisnis. Cetakan Keenam. Jakarta: Salemba Empat

Hasanah, Latiphah. (2017). Kegiatan Menganyam Untuk Meningkatkan Kemampuan Motorik Halus Anak Usia 4-5 Tahun Di RA Yahya A Bekasi. Jurnal: Paud UHAMKA. Vol. 2, No. 1, Januari, 2017.

Hurlock, E.B. (1978). Perkembangan anak jilid 1 edisi keenam. Jakarta: Erlangga.

Husaeri, Ahmad. (2018). Meningkatkan Kemampuan Motorik Halus Melalui Kegiatan Menganyam Pada Anak Kelompok A Di Tk Harapan 2 Jambesari Bondowoso. Skripsi Universitas Muhammadiyah Jember 
Jamaris, Martini. (2006). Pertimbangan dan Pengembangan Anak Usia TK. Jakarta : Gramedia Widia Sarana Indonesia

Khoerunisa, Ucu. (2019). Hubungan Antara Kegiatan Menganyam Terhadap Keterampilan Motorik Halus Anak Usia Dini. Penelitian di Kelompok B RA Al-Gozali Cileunyi, Bandung (Penelitian Kuantitatif Korelasional). Tesis Piaud UIN Sunan Gunung Djati, Januari

Mayesky, Mary. (2004). Creative Art \& Activities: Painting (Kanada: Thomson Delmar Learning

Miranda, D. (2016). Upaya Guru dalam Mengembangkan Kreativitas Anak Usia Dini di Kota Pontianak. Jurnal Pembelajaran Prospektif, Vol. 1, No. 1, 60-67, 2016.

Misiyanti, N. W., Parmiti, D. P., \& Wirya, I. N. W. (2014). Penerapan Metode Demonstrasi Berbantuan Media Konkret melalui Kegiatan Kolase untuk Meningkatkan Perkembangan Motorik Halus". Jurnal Pendidikan Anak Usia Dini Undiksha, Vol. 2, No. 1,

Muarifah, A., \& Nurkhasanah, N. (2019). Identifikasi Keterampilan Motorik Halus Anak. Journal of Early Childhood Care and Education, 2(1), 14. https://doi.org/10.26555/jecce.v2i1.564

Mulyadi. (2000). Merangsang Kreativitas Anak dan Kecerdasan Anak. Yogyakarta. 2000.

Munandar, Utami. (2004). Pengembangan Kreativitas Anak Berbakat. Jakarta: PT Grasindo, 2004.

Nuraeni, Oktavia. (2014). Peningkatan Keterampilan Motorik Halus Melalui Kegiatan Menganyam Dengan Kertas Pada Anak Kelompok B TK Sedyo Rukun Bambanglipuro Bantul". Skripsi Paud Universitas Negeri Yogyakarta

Pamadhi, Hajar, Evan Sukardi S. (2014). Seni Keterampilan Anak (cet.14). Universitas Terbuka

Prayitno. (2009). Dasar teori dan praksis pendidikan. Jakarta: Grasindo, 2009.

Suarni, Ketut. (2009). Psikologi Perkembangan I. Singaraja: Universitas Pendidikan Ganesha

Sujiono et al. (2008). Metode Pengembangan Fisik. Jakarta: Universitas Terbuka

Sumanto. (2005). Pengembangan Kreativitas Seni Rupa Anak TK. Jakarta: Depdiknas,

Suryana, Dadan. (2018). Stimulasi dan Aspek Perkembangan Anak . Jakarta: Prenadamedia Group

Susanti, Eva. (2020). Upaya Meningkatkanmotorik Halus Anak Melalui Kegiatan Menganyam Daun Kelapa Pada Kelompok B Tk Baladil AminLawe Sawah". Skripsi Piaud UIN Ar-Raniry, 2020.

Susanto, Ahmad. (2011). Perkembangan Anak Usia Dini. Jakarta: Kencana Prenada Media

Sutama. (2011). Metode Penelitian Pendidikan Kuantitatif, Kualitatif, PTK, R dan D. Surakarta: Fairus Media

Suyanto, S. (205). Dasar-dasar Pendidikan Anak Usia Dini. Yogyakarta: Hikayat Publishing

Widiastini, L. P., Raga, G., \& Kusmaryatni, N. (2014). Penerapan Metode Pemberian Tugas Berbantuan Media Bahan Alam untuk Meningkatkan Kreativitas Meronce Anak Kelompok B di TK Nurul Mubin". Jurnal Pendidikan Anak Usia Dini Undiksha, Vol. 2, No.1

Yulia, Ni Kadek Hari. (2013). Penerapan Model Pembelajaran Explicit Instructon Melalui Kegiatan Bermain Warna Untuk Meningkatkan Perkembangan Motorik Halus Anak Pada Anak Kelompok Bermain Gayatri Denpasar Utara. Skripsi. (tidak diterbitkan) Singaraja: Universitas Pendidikan Ganesha 